IFN Working Paper No. 1040, 2014

\title{
Re-Coinage in Medieval Sweden
}

\author{
Roger Svensson
}




\title{
Re-Coinage in Medieval Sweden
}

\author{
Roger Svensson *
}

\author{
Research Institute of Industrial Economics (IFN) \\ Stockholm
}

1 September 2014

Key words: Re-coinage, bracteates, medieval Sweden, coinage policies, monetization,
debasements.

JEL Codes: E31, E42, E52, N13

\begin{abstract}
In medieval Europe, old coins were frequently declared invalid and exchanged for new ones at fixed rates and dates. Here, the question of whether and when such re-coinage was applied in medieval Sweden is analyzed against the historical record. A theory of how short-lived coinage systems work is applied to Swedish coinage. It is shown that Sweden adopted similar coin types as those minted in Continental Europe in the Middle Ages, and also adopted the corresponding continental coinage and monetary taxation policies linked to these coin types. Swedish experience is extraordinarily well in line with what one would expect from the theory of short-lived coins. Economic backwardness, limited monetization of society and separate currency areas facilitated recoinage. Re-coinage with varying frequency was applied in 1180-1290 when only bracteates were minted. This is evidenced by many different coin types per reign, coin hoards which are dominated by a few types and dating of types to specific periods of the kings' reigns. However, monetization increased in the late $13^{\text {th }}$ century, making re-coinage more difficult. and bracteates were replaced by long-lived two-faced coins in 1290 . With an end to recoinage, the Swedish kings then accelerated the debasement of the long-lived coins. The disappearing re-coinage fees were compensated for by debasing the silver content. Such debasements - interrupted by several coinage reforms - were applied until the beginning of the $16^{\text {th }}$ century.
\end{abstract}

\footnotetext{
* Research Institute of Industrial Economics (IFN), P.O. Box 55665, SE-10215 Stockholm, Sweden. Correspondence: roger.svensson@ifn.se

I would like to thank Per Hortlund, Kjell Holmberg and Frédéric Elfver as well as the seminar participants at the Department of Economic History, Gothenburg University and at the SNEE-conference in Mölle for insightful comments. The author gratefully acknowledges financial support from the Torsten Söderberg Foundation and the Sven Svensson Foundation for Numismatics.
} 


\section{Introduction}

A goal of the minting authorities in medieval Europe was to create a preference for the issuer's coins compared to competing foreign coins, with sustained acceptance enhancing the issuer's profit. Therefore, legal tender laws stated that foreign coins were precluded from circulation. Foreign coins and bullion were to be exchanged for current coins at the mints. Here, the minting authority had an exchange monopoly and could thereby charge a gross seignorage (Kluge 2007:62-63).

A well-known monetary taxation method was to manipulate the weight and fineness of the coins. Such debasements often occurred in times of war or epidemic when finances were volatile and in disarray (Edvinsson 2011:168). ${ }^{1}$ Profits from debasements were based on secrecy and asymmetric information about fineness on the part of the coin issuer vis-à-vis the public. There were thus large transaction costs for people to detect debasements of fineness. A less well-known way to profit from minting was re-coinage (also coin renewals, or the Latin, renovatio monetae). Old coins were declared invalid and exchanged for new ones (with the same monetary standard) at fixed exchange rates by certain dates. In the Middle Ages recoinage could occur twice a year within a currency area. An exchange fee was charged as a way to tax trade and inhabitants. Such coins are called short-lived coins, compared to longlived coins that were valid during the whole reign of the coin issuer.

The first coinage in Sweden was temporary in nature (995-1030). On the mainland, the coinage was resumed in Götaland around 1153 and in Svealand around 1180. For almost 140 years (1153-1290) only bracteates were minted in Sweden. ${ }^{2}$ Thereafter, two-faced pennies (1290-1354) and bracteates (1354-65) were minted until the 1370s, when a system with Örtug (8 pennies) and hohlpennies was introduced that lasted for almost 150 years. The Swedish medieval coins are better documented with respect to coin issuers and mints than medieval coins from many other European countries, e.g. Germany and Poland (see e.g. Lagerqvist 1970).

However, there are still drawbacks with the Swedish literature about medieval coins. First, although coins are always economic instruments and function as a universal medium of

\footnotetext{
${ }^{1}$ The reason for debasement is likely either to make a higher profit from minting or to deflate debt.

${ }^{2}$ Bracteates are thin uni-faced coins that were struck with only one die. A piece of soft material, such as leather or lead, was placed under the thin flan. Consequently, the design of the obverse can be seen as a mirror image on the reverse of a bracteate.
} 
exchange and standard of value, the Swedish medieval coins have seldom been studied from an economic perspective. Second, Swedish medieval coins have seldom been analyzed from an international perspective, though they were strongly influenced by the continental coins. ${ }^{3}$ Third, it is still unclear which coinage and monetary taxation policies were applied in medieval Sweden. For example, it is well known that bracteates minted in continental Europe in the period 1140-1320 are strongly linked to systematic coin renewals. Although the bracteate was the only Swedish coin type in circulation in the period 1153-1290, earlier Swedish literature hesitates about the existence of such renewals.

The main purpose of this study is to analyze which monetary taxation and coinage policies Sweden applied 1153-1520. Empirical observations from Sweden will test the theory of how different coinage systems (short-lived and long-lived coins) work in theory and practice. The basic idea is that one can learn a substantial amount about Swedish medieval coinage by studying the nature of contemporary continental coinage. After all, the bracteate, the Örtug (Witten) and the hohlpenny were German innovations that Sweden and other countries adopted.

The study is organized as follows. Section 2 surveys basic information about medieval coins. In section 3, the theory and conditions of different coinage systems are outlined and their distribution in medieval Europe is empirically described. In section 4, Swedish medieval coins of different time periods are described and analyzed. In section 5, I apply the Swedish observations in section 4 to the theory of section 3 to determine which coinage systems were used in Sweden. The final section delineates the conclusions.

\section{Basics about medieval coins}

A coin is a piece of hard material that is standardized in weight and fineness. An authority guarantees the weight and fineness with a hallmark. To work as general purpose money, coins must perform three basic functions: as a medium of exchange, a standard of value/unit of account and a store of value. Generally, coins in medieval Europe did all three jobs

\footnotetext{
${ }^{3}$ The Swedish Viking-age coinage, around year 1000, was influenced by the English coinage. The bracteate technology was imported from Germany in the $12^{\text {th }}$ century. The system with Örtugs and hohlpennies introduced in the $14^{\text {th }}$ century was similar to the coinage in northern Germany (Witten and hohlpennies). Research focusing on Swedish Viking-age coins has had an international basis for several decades, for example in the set of studies in Corpus Nummorum Saecolorum IV-VI. Also Malmer (1980) had partly an international perspective when analyzing late-medieval Swedish hohlpennies.
} 
adequately, in the main as commodity money, i.e. the face value was very close to the intrinsic value. Fiat money where the value is not determined by the raw material value, but by the issuer's credibility or economy, did not then exist in pure form. If the weight or the fineness of commodity money declines, then the purchasing power of the coins to buy goods, services and assets also decreases. Precious metals (gold and silver) best fulfilled the requirements of commodity money and were used as raw materials in medieval coins. ${ }^{4}$ During the main period of the Middle Ages (ca. 700-1300), silver was almost the only key raw material in European coins. This depended on the existence of silver mines with a high supply of silver.

Normally, minted metal had premium value over un-minted metal in areas where the coins were legal tender, a disparity for which there are two basic economic explanations:

- First, minted metal works better as a medium of exchange and standard of value than does un-minted metal. When doing daily transactions it is easier to count coins than to weigh silver and to ascertain the fineness. People are thus generally willing to pay a premium to have their silver transformed into standard coins (Sussman 1993:50).

- Second, coins are a typical "network good". The individual value of holding coins increases the more people accept the coins as a medium of exchange and a standard of value (Dowd and Greenaway 1993:1180ff). Hence the premium component is reinforced and tends to grow.

In practice it is the agents in the market who determine the level of this premium component that enables the coin issuing authority to make a profit (gross seignorage) from minting. ${ }^{5}$

In the Middle Ages the king/emperor possessed the rights to mint, charge market customs and run mines. The coinage right encompassed the right to (Kluge 2007:52): 1) decide which coins are legal tender, i.e. which coins are legitimate and valid as a medium of exchange, 2) determine the monetary standard, including denomination, weight, fineness, diameter and relief, 3) coin and determine design and 4) make a profit from minting.

The coinage right could be delegated, sold or pawned to other authorities (laymen, churchmen, citizens) (Kluge 2007:53). In general, these authorities had to observe the king's

\footnotetext{
${ }^{4}$ Precious metals: 1) exist in limited quantities, are 2) well-known, 3) of stable value and 4) relatively soft and thereby easy to work up. The last characteristic implies coins cannot contain 100 percent gold or silver. Instead, these precious metals are mixed with zinc or copper - as the coins otherwise would be worn down in routine use.

${ }^{5}$ Gross seignorage $=$ net seignorage + production costs.
} 
guidelines for valid coins and the monetary standard. ${ }^{6}$ The rights to mint and charge market customs were typically delegated together, since the coin issuer also had to control the market. The market custom was a fee for the craftsmen and merchants' goods brought to and sold in the town market. This fee's stated purpose was to support the market, but it was also important recurring revenue for the authority.

The size of the currency areas bounding the right to mint could vary substantially in the Middle Ages. In England, Sweden and Denmark, the king normally retained the coinage right and had a pure monopoly. Exceptions were some mints controlled by bishops. The whole of England was a single currency area, while Sweden and Denmark each had 2-3 areas. These large currency areas had each several mints. In contrast, in France the minting right was delegated to many civil authorities and there were many small currency areas. However, the best examples of many small currency areas can be found in the politically decentralized Germany, where a city (mint) with its surroundings could constitute a currency area. Unlike in France, ecclesiastical authorities in Germany frequently received the coinage rights.

The minting authority could not strike as many coins as it wished. Context matters for the minting authority - there must always be a demand for coins as a medium of exchange in daily life. Otherwise, the surplus coins would overflow the market with higher prices as a consequence, and the coins' face value would be diminished towards their intrinsic value (Sargent and Velde 2003:18ff). Increased local trade will increase the demand for coins. Why then, it should be asked, did local trade then increase in the Middle Ages? In an economy with limited division of labour and where every household is in principle self-supporting, there should be no need for a local market and the associated coins for local transactions.

In the $12^{\text {th }}$ and $13^{\text {th }}$ centuries, population growth resulted in an increased division of labour among peasants, handicraftsmen and households. This should have resulted in two important consequences. First, efficiency in production should have increased, since some specialized in producing tools, while others specialized in producing shoes or clothes. Second, specialization leads to increased requirements for buying and selling goods and services in a local market, which in turn increased the demand for coins. Empirical research has documented that specialized workers (handicraftsmen) often settled down in the growing towns and cities

\footnotetext{
${ }^{6}$ The most common reason to delegate the coinage right was that a bishop or layman founded a town, and thereby financed the associated costs. But delegation could also be exchanged for loyalty to the king/emperor.
} 
(Steguweit 1987:16). Theoretically, craftsmen are more dependent on the local market and transactions than are peasants. The former have incentives to settle down close to the market. As a consequence, towns were founded and started growing.

Another persuasive explanation for the increased monetization of the economy was that the king or landlord preferred payment of taxes or rents in coins over traditional payment in kind or in services. The landlord could thereby select and purchase those goods and services that he wanted, instead of getting just those goods that his rent-paying peasants produced. Furthermore, the king/landlord was not required to move around between different estates to consume the goods. This made it possible for an aristocracy to settle down as a proto-leisure class in the towns (Spufford 1988:249). Finally, by himself accepting payment in coins, the issuer could strengthen the coinage and increase the demand for coins, and thereby the profit from minting.

The division of labour and the development of local markets must be in place before the landlord and other authorities require taxes and rents in coins. There are two reasons. Firstly, peasants must be able to sell some of their output in a local market in order to obtain coins. Secondly, it could only have been an advantage for the landlord to accept monetary rents if the local markets were already developed. He could then, but not before, more efficiently purchase what he demanded.

\section{Coinage policies in medieval Europe}

\subsection{Short-lived and long-lived coinage systems}

For purposes of analysis, the coinage systems in the High Middle Ages of Europe (ca. 10001300) are divided into two main systems. One system had long-lived coins that were valid during the whole reign of the coin issuer. ${ }^{7}$ The other system had short-lived coins that were only valid for specific intervals of the issuer's reign. ${ }^{8}$ In the latter system, old coins were frequently declared invalid and exchanged for new ones at publically announced dates. The monetary standard (denomination, weight, fineness, diameter, and shape of the flan) remained the same at re-coinage, only the image of the coins was changed. An exchange fee was

\footnotetext{
${ }^{7}$ Sometimes, successors minted variants of the same coin type. These are called immobilized types and could be valid for very long periods - occasionally centuries - surviving through the reigns of several new rulers.

${ }^{8}$ The term "regional coins" is widely used instead for short-lived coins in the numismatic literature. But the term "regional" is misleading inasmuch as also long-lived coins had a geographical constraint and were regional.
} 
charged on the re-coinage date as a way to tax trade and inhabitants. For example, the fee could be four old coins for three new ones, i.e. a gross seignorage of 25 percent.

There is a consensus in the conclusions drawn about the extension through time and space of long-lived and short-lived coinage systems. As can be seen on Map 1, long-lived coins were common in western and southern Europe (France, Italy, Christian Spain and England after 1150) in the High Middle Ages, whereas short-lived coins dominated in central, northern and

Map 1. Short-lived and long-lived coinage systems in Europe 1140-1300.

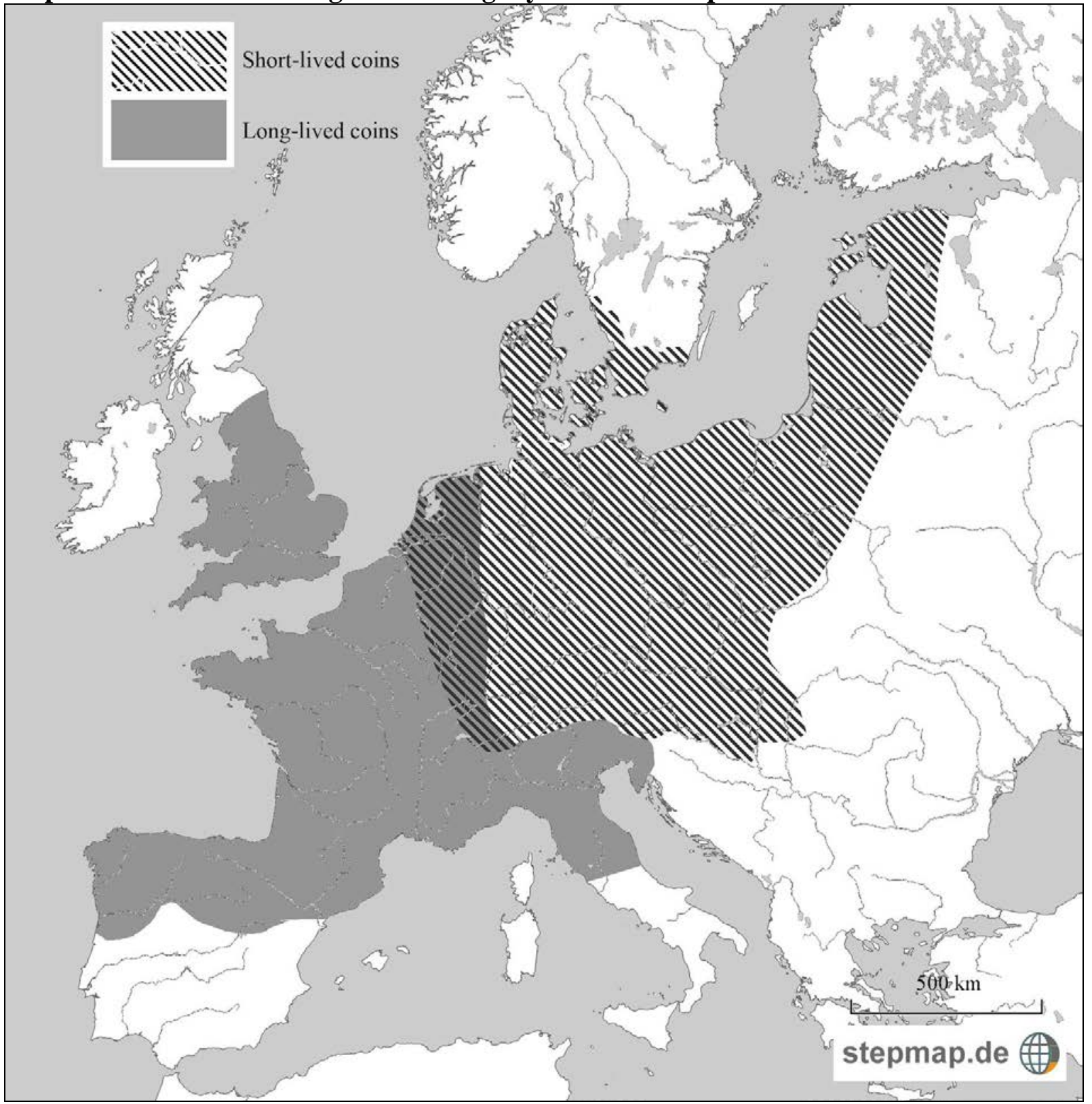


eastern Europe (Germany, Austria, Denmark, Poland, Bohemia/Moravia and England before 1150) (Kluge 2007:62ff). The best examples of short-lived and geographically constrained coins can be found in central and eastern Germany where currency areas were relatively small. Here, re-coinage started in the middle of the $12^{\text {th }}$ century and lasted until the beginning of the $14^{\text {th }}$ century and could occur annually or twice a year (Kluge 2007:63). The short-lived coinage system defined legal tender for almost 200 years in large parts of medieval Europe. ${ }^{9}$

\subsection{Identifying coinage systems}

There are several basic methods for identifying re-coinage. In Table 1, I have ranked the methods by confidence. The most confident way to identify re-coinage is through written documents that may contain explicit information about dates of re-coinage and/or exchange fees (method A). However, there are no written sources about recurrent re-coinage for some currency areas and mints and other methods must be used.

Table 1. Methods to identify short-lived and long-lived coinage systems

\begin{tabular}{llccc}
\hline \hline Method & Long-lived coins & Short-lived coins & Confidence of method \\
\hline \hline A & Written documents & ---- & ----- & Very strong \\
\hline B & $\begin{array}{l}\text { Coin types per reign and } \\
\text { currency area }\end{array}$ & One & At least two & Strong \\
\hline C & Coin types in hoards & $\begin{array}{c}\text { One or a few from } \\
\text { each mint }\end{array}$ & $\begin{array}{c}\text { Many from each mint, } \\
\text { but a few late dominate }\end{array}$ & Medium \\
\hline D & Imitations of popular types & Often & Rare & Weak \\
\hline
\end{tabular}

By classifying different coin types as originating from a specific coin issuer and mint (method B), it is easy to establish whether re-coinage must have occurred. If there is only one type per reign, the coinage system is long-lived. However, in the event there are as many types as years of a specific reign and mint, the evidence indicates annual renewals. If the number of types exceeds (falls short of) the number of years, the renewals are more (less) frequent.

\footnotetext{
${ }^{9}$ England had re-coinage ca. 975-1130/35, as did eastern parts of France and western parts of Germany in the $11^{\text {th }}$ and $12^{\text {th }}$ centuries (Spufford 1988:92ff, Hess 2004:19-20). Like Germany, Poland had many currency areas and minting authorities. At the end of the $12^{\text {th }}$ century renewals were annual, and in the $13^{\text {th }}$ century they occurred twice a year (Suchodolski 2012:341ff). Bohemia also had re-coinage at least once per year in the $12^{\text {th }}$ and $13^{\text {th }}$ centuries (Sejbal 1997:83, Vorel 2000:26). Austria had annual re-coinage until the end of the $14^{\text {th }}$ century and Brandenburg from around 1150 until 1369 (Kluge 2007:119), and the Teutonic Order in Eastern Prussia every tenth year between 1237 and 1364 (Paszkiewicz 2008:178). The King of Denmark introduced frequent re-coinage (mostly annual) from the middle of the $12^{\text {th }}$ century that continued for 200 years with some interruptions (Grinder-Hansen 2000:61ff).
} 
A third method for identifying re-coinage involves carefully analyzing the concentration and distribution of types in coin hoards (method C). Coin hoards from the Middle Ages may contain few or many issues from each mint represented in the hoard. If re-coinage has occurred, one would expect a few types to strongly dominate the composition of the hoard. These types would be relatively young, while older types should have a more sparse representation. If there are several coin hoards from a specific coin issuer, one can expect the types existing in many hoards to be older and those in a few hoards to be younger.

A fourth method for identifying the coinage system involves recognizing the existence of imitations (method D). Some long-lived coin types with high silver content were viewed as so stable that they were imitated by other minting authorities. ${ }^{10}$ Conversely, imitations of shortlived coins were far less common. This pattern is easy to understand - a coin that only lives for just one year will neither be well-known nor regarded as stable by neighboring mints or regions. This fourth method is the weakest technique since many long-lived coins were never imitated.

\subsection{Conditions for short-lived coinage systems}

The basic similarities and differences between the coinage systems are depicted in Table 2 . Both short-lived and long-lived coinage systems require a geographical currency constraint (foreign coins are invalid) and an exchange monopoly. Furthermore, the coin issuing authority must control both the local market and the coinage. This is facilitated if the rights to charge market customs and to mint are possessed by a single authority, which in medieval Europe normally was the case (Kluge 2007:63).

If a system with re-coinage is going to be practical, it is essential that: 1) only one type circulates; and 2) it is easy for users in everyday life to distinguish between various issues. It is then logical that differences in the main design on the coins are linked to different issues, while more difficult to see details are used by the minting authority to control the coinage. ${ }^{11}$

As noted previously, re-coinage was the dominant monetary policy in the central, eastern and northern parts of Europe. These areas were relatively undeveloped and had less experience of

\footnotetext{
10 This occurred to some extent in the Early (800-1000) and High Middle Ages (1000-1300), but became even more common in the Late Middle Ages (1300-1500). Commonly imitated late medieval coins included the English Sterling, the French Gross Tournois, the Sicilian Gigliato, the Prague Groschen and the German Witten.

${ }^{11}$ The details may represent different mints, weights, fineness or mint masters.
} 
coinage and local markets than western and southern Europe. Re-coinage works particularly well in relatively undeveloped economies, since there is a small volume of coins circulating. This key factor facilitates re-minting. Furthermore, there are also few places where coins are used for transactions and few groups in society who use coins, i.e. low monetization. The latter facts facilitate monitoring and enforcement of a short-lived coinage system (Svensson 2013a:9-10).

Table 2. Similarities and differences between long-lived and short-lived coinage systems.

\begin{tabular}{|c|c|c|}
\hline Conditions/Characteristics & $\begin{array}{l}\text { Long-lived } \\
\text { coins }\end{array}$ & $\begin{array}{l}\text { Short-lived } \\
\text { coins }\end{array}$ \\
\hline "Geographical constraint (foreign coins invalid) & Yes & Yes \\
\hline Exchange monopoly & Yes & Yes \\
\hline Market right necessary & Yes & Yes \\
\hline Minting of bullion (gross seignorage) & Yes & Yes \\
\hline $\begin{array}{l}\text { Profit of the } \\
\text { coin issuer }\end{array}$ & Yes & Yes \\
\hline Re-coinage and issues (exchange fee) & $\begin{array}{l}\text { Only when shift } \\
\text { of issuer }\end{array}$ & Frequent \\
\hline Debasements of weight and fineness & Often & Sometimes \\
\hline $\begin{array}{l}\text { Number of coin types (same denomination) circulating } \\
\text { simultaneous in a given currency area }\end{array}$ & One or few & One \\
\hline Volume of coins circulating in the economy & Large & Small \\
\hline Relative development of the economy & High & Low \\
\hline Geographical area & Large or small & Preferably small \\
\hline Number of mints in large currency areas & Few & Many \\
\hline
\end{tabular}

Typically a short-lived coinage system with only local new coins as legal tender was enforced only within a city's borders in Germany, and any coins could be used outside the city (Hess 2004:16). The coin issuing authority had several methods to monitor and enforce the recoinage. First, they had exchangers and other administrators at the city markets. Second, the re-coinage date was often designated just prior to an important annual market or payment date of an annual tax. Third, payment of any fees, taxes, rents, tithes or fines had to be made in new coins (Svensson 2013b:13ff).

Re-coinage was especially frequent in areas where uni-faced bracteates were minted; usually annually but sometimes twice a year (Kluge 2007:63). Bracteates had several favourable characteristics for such a policy: 1) Low production costs - only one die was needed and the bracteate dies lasted longer than dies for two-faced coins; 2) Old bracteates were easy to hammer out and overstrike; 3) A large variety of pictures could be displayed on the relatively 
large diameter, making recognition of valid and invalid coins fast and reliable. The fragility of the bracteates was not a big problem, since the bracteates would not circulate for a long period.

In Germany in the period 1140-1300 two-faced coins and bracteates were minted simultaneously. The former were struck in the western parts of Germany, Westphalia, the Rhineland and Franconia; the latter in the rest of the territory. The bracteates got a foothold in regions with comparatively less experience of monetary economics and where no monetary standard existed. Both two-faced coins and bracteates were linked to re-coinage in Germany. Regions where bracteates were struck had more frequent renewals - sometimes as often as every half a year. This is logical, since frequent renewals require a low monetization. The renewals in the western parts of Germany had already had passed zenith when the use of bracteates emerged and spread in the 1140s. The dominant mint in the Rhineland, Cologne, renewed its coinage every fourth or fifth year.

\subsection{Alternative monetary taxation policies}

As mentioned in the introduction, there were two main methods (besides re-minting of foreign coins and bullion) of using the coinage as a monetary tax: re-coinage and debasement. Recoinage of course by definition always occurs in a short-lived coinage system, but never in a long-lived system. Debasement can occur in all coinage systems. Thus, re-coinage and debasement are not inherently mutually exclusive and can be in place simultaneously. ${ }^{12}$ Both types of monetary taxes will cause old coins to be driven out of circulation, either through administrative re-minting (re-coinage) or due to Gresham's Law (debasement).

Empirical evidence shows that debasement mostly occurred in long-lived systems, where the issuer's revenue from minting was limited. This was especially the case in medieval France, Spain and Italy (compare with Map 1) (Kluge 2007:64). For many regions of Germany, as long as re-coinage occurred, the silver fineness was sustained at a high level of at least 90 percent. It was not until the $14^{\text {th }}$ century, when long-lived coins replaced short-lived ones, that debasements accelerated in Germany (Gaettens 1963:18, 35, 58, Jesse 1967:209 and Svensson 2013b, Chapter 3).

\footnotetext{
${ }^{12}$ For example, this was the case in Denmark during a civil war between 1260 and 1340 (Grinder-Hansen 2000:67ff).
} 


\section{Coinage in Sweden 1153-1523}

\subsection{Different currency areas}

In the mint Sigtuna (Svealand), two-faced coins inspired by English coins were struck from 995 to 1030. Studies of dies and die-links show that the quantity of minting in Sigtuna was considerable (Malmer 2010). No real state called Sweden existed during this period. The minting ceased around 1030, for hitherto unexplained reasons.

The area in the $11^{\text {th }}$ and $12^{\text {th }}$ centuries that later would be called Sweden consisted of three independent regions (Svealand, Western Götaland and Eastern Götaland) with their own regional laws. Different dynasties competed for sovereign power in these regions during this period. A real central authority with a distinct central administration and royal tax collection was not established until the late $12^{\text {th }}$ century or early $13^{\text {th }}$ century. The ecclesiastical power started to become established in the $11^{\text {th }}$ century, and many churches were built in the $12^{\text {th }}$ century. Sweden lagged behind other countries in northern and central Europe, e.g. Denmark and Germany, both politically and economically. Above all, the economic backwardness is evidenced by the few towns and the lack of a local coinage system.

There were three monetary standards and currency areas in Sweden from 1153 to 1250: Svealand pennies, Geatish pennies (Western Götaland) and Gotlandic pennies (Gotland and Eastern Götaland) (Map 2). ${ }^{13}$ Gotland was in a kind of union with Sweden, but retained a selfgoverning position and its own coinage right (see section 4.4). In the middle of the $13^{\text {th }}$ century two Svealand pennies had the same value as three Gotlandic or four Geatish. ${ }^{14}$ Svealand bracteates weigh ca. $0.30 \mathrm{~g}$ and Geatish ca. $0.15 \mathrm{~g}$, which both had a silver fineness of 94 percent until 1250. This view of separate currency areas is in the main supported by the fact that the design and style of the bracteates in Svealand and Götaland are very dissimilar. Like regional laws, the coinage had a geographical constraint in Sweden, which was more a union of discrete regions under a common king. This arrangement - with different currency areas under the control of the same minting authority - closely matches the pattern in continental Europe (see Svensson 2013b, chapter 4).

\footnotetext{
${ }^{13}$ The currency areas almost coincided with the dioceses in: 1) Uppsala, Västerås and Strängnäs, 2) Skara and 3) Linköping and Växjö (Jonsson 2002:51). The dioceses and the monetary standards were also related to each other in Germany (see Nau 1977:94 and Svensson 2013b, chapter 4).

${ }^{14}$ One mark pennies consisted of 192 Svealand, 288 Gotlandic or 384 Geatish pennies, respectively.
} 
Map 2. Currency areas in Sweden until 1250.

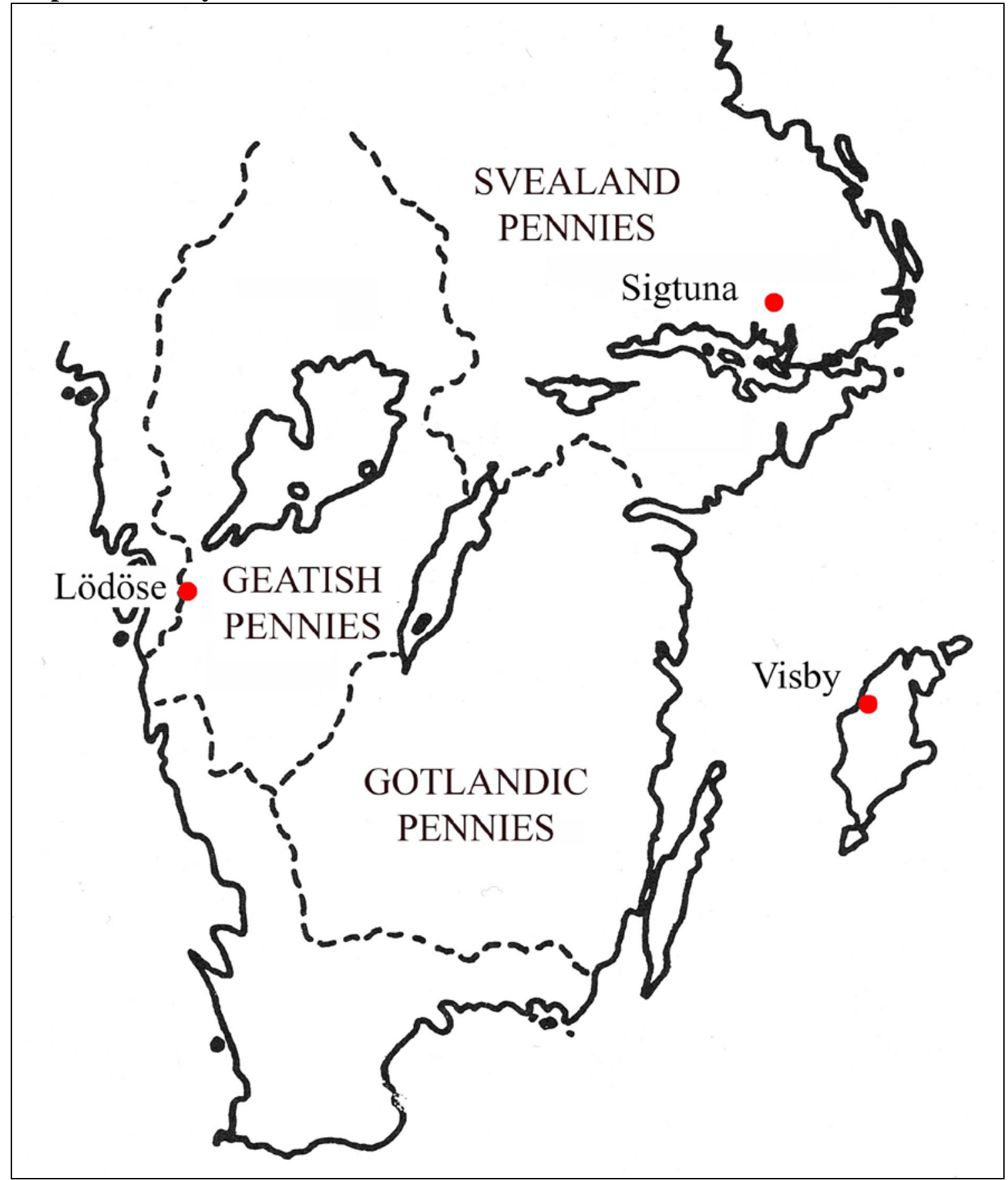

Note: Red dots represent known Swedish and Gotlandic mints in the $12^{\text {th }}$ century. Source: Jonsson (1995:51).

\subsection{The bracteate period 1153-1290}

On the mainland there was a long break of the coinage for around 120 years. The minting was resumed in Lödöse (Western Götaland) around 1153 (Ekre 1988:30). ${ }^{15}$ For the next 140 years,

\footnotetext{
${ }^{15}$ For a long time it was uncertain whether any coins had been minted in the Swedish area in the period 115080. For example, in an important reference work by Lagerqvist (1970) there are no listed Swedish bracteate types from this period. However, archaeological digs in Lödöse in the 1980s found a mint house and waste products from minting dated to the period 1150-70 (Ekre 1988:30).
} 
until 1290, only bracteates were minted on the mainland. Not much is known about the earliest bracteates (1150s) in Lödöse, apart from that it was an ecclesiastical issue as documented by the image of the double cross (Arnell 2001:4ff). Also the Skara bishopchronicle tells that the Skara-Bishop Bengt (ca. 1150-90) paid with his coins (Klackenberg 1992b:125). There are no written documents about re-coinage and only few coin hoards and cumulative finds from churches in the period 1153-80. The sparse available evidence means to date it is unsettled whether the early bracteates were short-lived or long-lived coins.

It is not until the later period (after 1180) of King Canute I's reign (1167-96) that several types of bracteates are continuously minted in Sigtuna (Svealand) and Lödöse (Götaland). ${ }^{16} \mathrm{~A}$ rigorous survey of listed and identified bracteate types shows that Canute I minted at least 15 different types in Sigtuna (Svealand) and 3 types in Lödöse (Western Götaland) in the period 1180-96 (Lagerqvist 1970). ${ }^{17}$ Thus, King Canute issued several types in both mints, within a limited time period (method B in Table 1). These observations suggest that renewals occurred in both areas, but were more frequent in Svealand than in Götaland.

Another important empirical observation which adds credence to the thesis of prevalent recoinage derives from interpreting the large coin hoards (more than 10 coins) from the reign of Canute I. The composition of these hoards is strongly skewed with respect to various bracteate types (method $\mathrm{C}$ in Table 1). Often, one or a couple of types dominate, indicating that they are late types, e.g. the hoards from Gillberga ${ }^{18}$ and Mackmyra ${ }^{19}$ (Jonsson 1983:79). It is difficult to imagine coin hoards more unbalanced than these in order to support the view that the types are chronological. In Germany and Denmark we are quite certain that recoinage has occurred, based on written sources. However, the German and Danish coin hoards are seldom if ever as unbalanced as the Swedish hoards from this period (Haupt 1954, Hävernick 1955, Gaettens 1963 and Grinder-Hansen 2000).

\footnotetext{
${ }^{16}$ The design of the Svealand bracteates has an obvious German influence - crowned bust or head with royal symbols in the hands. The first Svealand bracteates with a relatively high artistic style were likely struck by a German mint master. However, the style and design degenerated fast and within a decade the portrayed figure consists of pellets. This simplification of the design may be because once everyday users of the coin were familiar with the representation it was no longer necessary to waste resources on detailed designs. The Götaland types show variants of a crowned head.

${ }^{17}$ According to Jonsson (1995:54), some of the Svealand types may have been minted by the successor King Sverker II the Younger (1196-1208).

${ }^{18}$ The hoard from Gillberga in Uppland contains 457 bracteates from Canute's era, distributed in four types. Of these, more than 99 percent are of two types (431 of one type and 22 of another type).

${ }^{19}$ The Mackmyra hoard from Gästrikland has 235 bracteates distributed in 13 types, with 108 of one type and 21 of a closely related type. Two other distinctive types have 38 and 32 artefacts, and six types are evidenced by a maximum of two coins each.
} 
Table 3. Coining of bracteates in Sweden 1180-1290.

\begin{tabular}{lcccc}
\hline \hline Royal coin issuers & $\begin{array}{c}\text { Years of } \\
\text { issuing }\end{array}$ & Svealand types & Götaland types \\
\hline \hline Canute I Ericsson (1167-96) & 16 & $15^{\mathrm{a}}$ & 3 \\
\cline { 1 - 3 } Sverker II the Younger (1196-1208) & 12 & $3-4$ & 3 \\
\hline Eric X Knutsson (1208-16) & 8 & 6 & $1^{\mathrm{b}}$ \\
\hline John I Sverkersson (1216-22) & 6 & 6 & $2^{\mathrm{c}}$ \\
\hline Eric XI Ericsson (1222-29, 1234-50) & 23 & 9 & 0 \\
\hline Canute II the Tall (1229-34) & 5 & 0 & 4 \\
\hline Valdemar (1250-75) & 25 & 3 & 3 \\
\hline Magnus III Barnlock (1275-90) & 15 & 6 & 0 \\
\hline
\end{tabular}

Note: The number of different types refers here to types that are easily distinguishable from each other.

${ }^{\mathrm{a}}$ These bracteates were once attributed to Canute I, but some of them may have been minted by Sverker II.

${ }^{\mathrm{b}}$ Many variants of this type.

c These may be Svealand half pennies. Same images as the Svealand types images.

The Swedish kings in the first half of the $13^{\text {th }}$ century minted several types of bracteates in both Svealand and Götaland. The bracteate types within each region have the same style, but clearly visible differences in their designs. From the reign of Eric X (1208-16), three or four different Svealand types and one Geatish type are known (Holmberg 1995:68-69). ${ }^{20}$ Six Svealand and two Geatish bracteate types have been attributed to the reign of King John I (1216-22). These types are very rare in coin finds, but all of them are included in a coin hoard from Dimbo (Western Götaland). Jonsson (1999:77) suggests, given that the number of types in the hoard corresponds to the number of years, that annual renewals were introduced by John I in Svealand in 1216.

The next Swedish king, Eric XI, had two separate reigns (1222-29 and 1234-50). He minted more bracteate types in Götaland (8) than in Svealand (6). It is noteworthy that two issues had the same main design in both currency areas, e.g. a bird and a crowned head. It has been possible to date the various types to different periods of his reign (Holmberg 1995:68ff). This strongly adds further weight to the proposed hypothesis of re-coinage. For the reign of King Canute II the Tall, 1229-34, as many as nine Svealand bracteate types have been found in a coin hoard from Eskilstuna (Eastern Svealand). At least seven of them were issued by the king, and two further types may be dated to his reign. This indicates that re-coinage occurred annually or even more frequently in Svealand. No bracteates of Geatish monetary standard are

\footnotetext{
${ }^{20}$ There are a lot of variants of the Geatish type with the image of a crowned head. It is unclear whether these are different chronological issues.
} 
known. Therefore, it is doubtful if Canute II the Tall was accepted as king in the whole of Sweden (Holmberg 1995:71-72).

As previously mentioned, the coinage right could be delegated to ecclesiastical or civil authorities, conditional on obeying the guidelines from the king. Delegation occurred mostly when the royal power was weak, as was the case in Germany from 1100-1300, Denmark from 1130-57 and 1229-1340 and in Sweden from 1150-1275. The Archbishops of Uppsala minted bracteates, probably in Sigtuna, in the period 1190-1215 (Jonsson 1983:83). The bracteate types of the kings and the archbishops have the same monetary standard, so they could circulate simultaneously. From 1215 onwards there are no ecclesiastical coin issuers, indicating that the royal power had strengthened its position against the church. Earls only minted bracteates in the period 1229-66 in Sweden.

After 1250, the minting volume increases when Western and Eastern Götaland are joined to a uniform currency area. Several new mints were established. The Swedish bracteates until 1250 had as high fineness as the German, ca. 95 percent, but it declines to 80 percent in the period 1250-90 (Jonsson 2002:48-49, Gaettens 1963:18, 35, 58, Jesse 1967:209). The number of bracteate types per time frame was considerably fewer from 1250-90 than 11801250. King Valdemar (1250-75) struck only four main types of Geatish bracteates over his 25 year reign (Holmberg 1995:74-75).

It is not until the reign of King Magnus III Barnlock (1275-90) that Svealand and Götaland are joined in a common currency area. Both Svealand and Götaland then minted corresponding types with the same image, but the Svealand types were as usual double the weight of the Geatish (Jonsson 2002:50). ${ }^{21}$ The first main type was a crown in smooth edge, issued in several variants. Later two coin types with the letter $\mathbf{M}$ were minted, both with smooth and ray edge. Swedish numismatists have looked closely at these bracteates. King Magnus' last will of 1285 mentions four mints in Svealand (Uppsala, Örebro, Västerås and Nyköping) as well as in Götaland (Skara, Jönköping, Skänninge and Söderköping). This has been interpreted as suggesting that eight types had been minted, each in a different mint

\footnotetext{
${ }^{21}$ Also a Geatish bracteate with the letter $\mathbf{E}$ in similar style has been struck in the mint Kalmar, which was pawned to the Counts of Holstein.
} 
(Lagerqvist 1970:58). Attempts to match each variant to each mint using both stray finds and coin hoards have failed (e.g. Myrberg 1995). ${ }^{22}$

An interesting observation is that the small hoard from Lagmansberga with 30 M-bracteates contains only the four bracteate variants with smooth and not ray edge (Myrberg 1995:18). Statistical analysis shows the $\mathbf{M}$-bracteates with smooth (older) and ray (younger) edge represent two different issues (Svensson 2013b:214ff). To the best of my knowledge, no minting authority in medieval Europe ever struck bracteates with smooth and ray edge simultaneously within a currency area. The $\mathbf{M}$-bracteates were probably minted over at least 10-12 years, implying 5-6 year intervals between the renewals. ${ }^{23}$ The fact that other hoards from the Magnus III period contain bracteates with both smooth and ray edge indicates that the renewals were relatively inefficient. However, it is also in this time period that the shortlived coin system was abandoned, giving the long-lived coins a secure foothold.

\subsection{Long-lived coins and debasements 1290-1523}

A large coinage reform was undertaken around 1290 by the advisors of King Birger (12901318). Bracteates were replaced by two-faced pennies with a crown on the obverse and various large letters on the reverse. The interpretation of the letters has been debated, but it is very dubious if the types with different letters mark any internal chronology. ${ }^{24}$ A very important empirical observation - that not a single variant of the crowns on the obverse can be found on two coins with different letters on the reverse (Jonsson 1977:120-21) - suggests that the systematic re-coinage was put to an end in Sweden in $1290 .^{25}$

The Svealand monetary standard was adapted across the whole mainland of Sweden in 1290, but only two-faced pennies were being minted then. In the reign of King Birger the fineness

\footnotetext{
${ }^{22}$ Her hypothesis is that bracteates struck in a mint will be found primarily in nearby coin finds. However, although this method which hinges on the vital role of proximity seems at first to be common sense, it is inherently unreliable when the currency area is large and there are several mints. In that context the coins will circulate in the whole currency area where they are valid. Both the stray finds and coin hoards confirm this critical view.

${ }^{23}$ The different shapes of the M's and the details (pellets) would then possibly represent mints.

${ }^{24}$ The interpretation of the letters is inconsistent and not yet determined. Jonsson (1977:125) means that some letters represent different mints (I, K, L, $\mathbf{O}$ and $\mathbf{S}$ ), whereas others refer to the issuer - $\mathbf{B}$ for King Birger and $\mathbf{E}$ and $\mathbf{W}$ for his brothers, Dukes Erik and Waldemar. For two letters, $\mathbf{M}$ and $\mathbf{R}$, there are no suggestions about their reference.

${ }^{25}$ If re-coinage occurred, then the letters on the reverse would represent different issues. In such cases, at least one specific crown variant on the obverse should have been used for two reverses with different letters. However, such a die-link has not been found on the existing coins from King Birger.
} 
declined further to 63 percent, which was maintained until the 1350s (Jonsson 2002:49). ${ }^{26}$ King Magnus IV (1319-63) undertook a coinage reform with a new type of two-faced coin (Lion left or right on the obverse and crown on the reverse) when he entered the throne in 1319 and undertook a re-coinage in 1340, when only the image of the coins (Lion left on the obverse and different letters or symbols surrounded by three crowns on the reverse) was changed.

According to Edvinsson (2011:70) the debasements of fineness accelerated in the period 1352-54. Non-Swedish written sources based on the payment of the Peter penny to Rome claim that the exchange rate between mark silver and mark pennies was worsened from 1:5 to 1:8 in a few short years. However, it is uncertain which specific Swedish coin type can be linked to this dramatic revaluation. It is quite plausible to argue that the Swedish church paid the Pope in Rome with debased Norwegian pennies. According to Lagerqvist (1970:93), Sweden and Norway may have had a monetary union during large periods of the reign of Magnus Eriksson, who was King of both Sweden and Norway. The best current evidence to date of this tie is that the same coin types ( $L L X X I X)$ routinely appear in coin finds in both Sweden and Norway.

In 1354, the two-faced pennies were exchanged for hohlpennies with a crown or letter in ray edge. It is important to mention the Black Death (ca.1350-55) here, as afterwards the state finances must have been in extreme crisis. The fineness of these bracteates fell continuously from 45 to 10 percent until 1363. People’s confidence in the Swedish coinage must have been in freefall as it appeared close to a collapse. It was against this backdrop of a clear downward economic spiral that led to the system being reformed in 1363. The hohlpennies with ray edge were replaced by hohlpennies with a letter and smooth edge. The new hohlpennies had a fineness of around 90 percent and were struck until 1365.

The Swedish coinage system was reformed and the Örtug (eight pennies) introduced as the main denomination around 1370. Hohlpennies with the denomination one penny were then minted as small change. Once again, the German monetary system (Witten and hohlpennies) was the prototype for the Swedish coinage. The system with Örtug and hohlpennies is a

\footnotetext{
${ }^{26}$ As a consequence, the bracteates of Magnus III were crowded out by the new low-fineness coins (Gresham's Law). In the coin hoards from the reign of Birger, there is not a single bracteate minted by Magnus III prior to 1290.
} 
typical long-lived coinage. The Swedish hohlpennies have the designs of a crowned head, crowned S or crowned $\mathbf{A}$, representing the mints Stockholm, Söderköping and Västerås or Åbo (Turku). These types were minted for almost 150 years, until the early $16^{\text {th }}$ century and can thus be regarded as immobilized types (see section 3.1). Malmer (1980) has classified and dated them. Different details, the form of the design and not least the fineness all point to which king minted them. In particular, the debased fineness is characteristic of the late medieval Swedish Örtugs and hohlpennies. This is in line with the theory about long-lived coins in section 3.4. For the type with a crowned head, the fineness declined from 75 percent in the 1360s to 19 percent by around 1500 (Malmer 1980:15, 43). For the hohlpenny with a crowned A, it declined from 50 percent to 19 percent (Holmberg 2009:94).

Figure 1. The development of fine weight in one mark pennies in Sweden 1180-1520

Silver content $(g)$ in one mark pennies

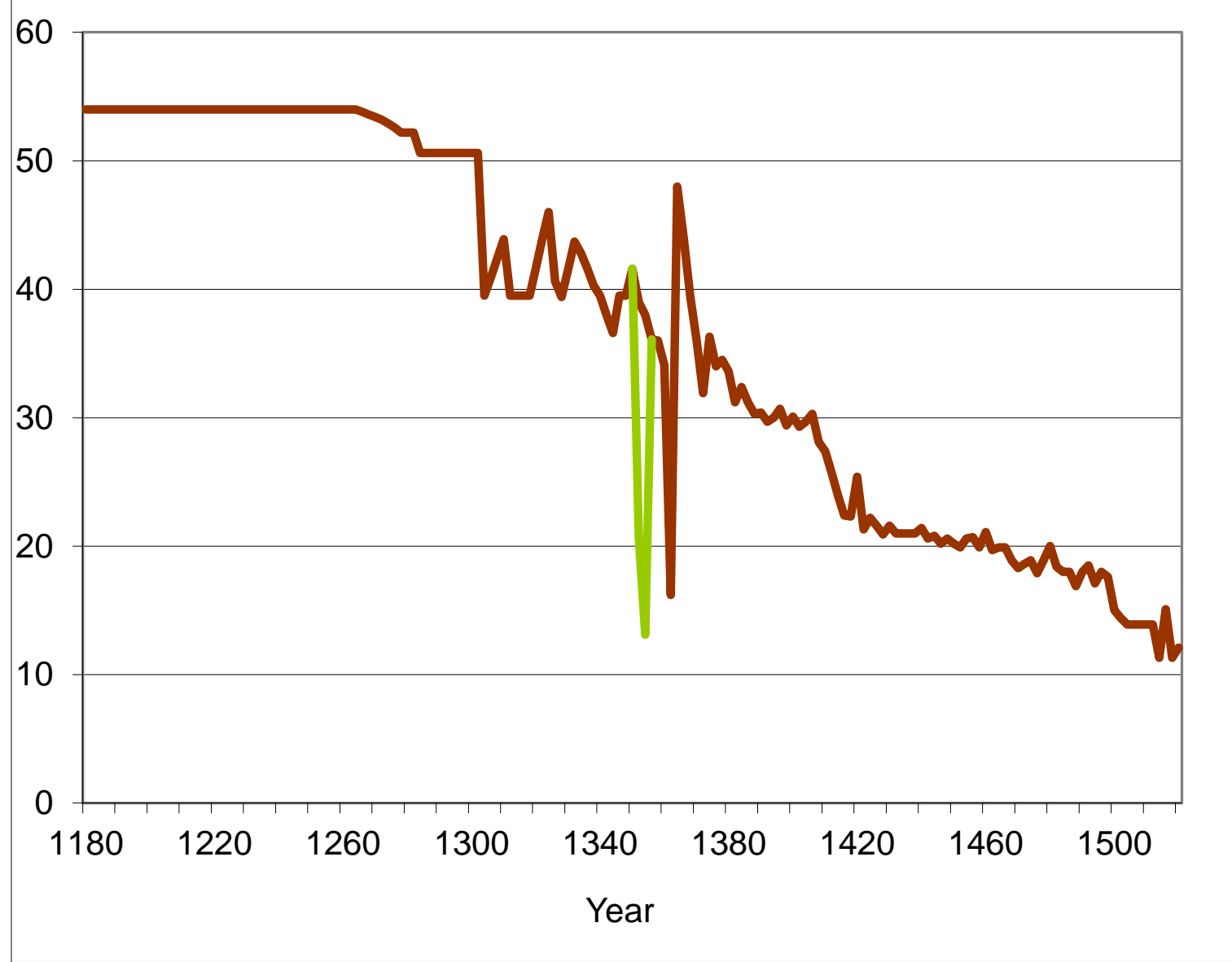

Note: One penny weighs $0.3 \mathrm{~g}$ and there are 192 pennies per mark. If the silver fineness is 94 percent, then one mark pennies weighs $54 \mathrm{~g}(192 * 0.3 * 0.94)$. The green curve indicates a possible debasement from 1352-54, based on non Swedish sources (Edvinsson 2011:170). Before 1275, one mark pennies refers to Svealand pennies. One mark silver equals ca. $210 \mathrm{~g}$.

Source: Edvinsson et al. (2010:77) and my own revisions. 
The development of the silver content, in one mark of the pennies $1180-1520$, is shown in Figure 1 . If the penny $(0.3 \mathrm{~g})$ has a fineness of 94 percent, then one mark pennies contains 54 g silver (192 pennies/mark * $0.3 \mathrm{~g} * 0.94)$. As already emphasized, there are hardly any changes at all in either the weight or fineness prior to 1250 . The debasements that began at the close of the $13^{\text {th }}$ century accelerated during the reign of King Birger (1290-1318). There are two severe debasements at the end of Magnus IV's reign, 1352-54 and 1354-63; the first is uncertain and marked with a green curve (see earlier discussion). During the hohlpennyperiod (1370-1520), the fineness with stops and starts continuously declined.

\subsection{Gotland}

The minting in Gotland started around 1140 in Visby. During the next 80 years a two-faced simple thin coin type was struck and dominant for long periods. Between 1220 and 1245 a few other types were minted, but between 1245 and 1288 once again a uniform type was coined (Myrberg 2008:177, Jonsson 2002:46-47). These should have been long-lived coins. The weight and the fineness declined continuously in the period 1140-1220, especially after 1200 (Myrberg 2008:75ff). The spread of the Gotlandic pennies evidenced in hoards is relatively wide; they dominate the composition of coin hoards both in Eastern Götaland and the Baltic area. The large spatial dispersion of the coins across seas and rivers, and the fact of the long temporal period of their minting, together indicate the purpose was to use them effectively in trade and for the local markets. The coin issuing authority seems to have been primarily interested in the stability of the coinage. Therefore, a trade organisation or the city of Visby could well have been the issuer (Jonsson 1995:52-53).

Around 1340, the Gote (twelve pennies) was introduced (ca. 1.3 g). This was the first coin with a high denomination in the Baltic Sea region. Simple bracteates as well with the letter $\mathbf{W}$ were struck from the end of the 1280s, initially as the main coin and eventually as small change to the Gote. In principle, it is the same main type of $\mathbf{W}$-bracteates that were coined for over 160 years. The silver fineness both for the Gotes and the bracteates severely declined in the 1440 s.

\section{Discussion}

There exist no written documents about re-coinage in Sweden from the $12^{\text {th }}$ and $13^{\text {th }}$ centuries. Therefore, I compare the conditions in Sweden for regions using short-lived coins (see Table 
1). A chief characteristic of regions with short-lived coins is that the economy is relatively undeveloped. The facts that continuous minting did not start until the 1150s, and that there are only a few towns in the $12^{\text {th }}$ century - Sigtuna, Uppsala and Västerås in Svealand, and Lödöse and Skara in Western Götaland, underscore how undeveloped Sweden was when compared to Germany and central Europe. Gotland, a trade centre in the Baltic Sea since the Viking-age, should have been more developed than the Swedish mainland. Logically, long-lived coins were minted here. What is surprising about Gotland is that minting did not start until 1140.

Another condition for re-coinage is that there are few coins in circulation. According to Klackenberg (1992a:179ff), Sweden was not fully monetized until the late $13^{\text {th }}$ century (Götaland) or early $14^{\text {th }}$ century (Svealand). ${ }^{27}$ This conclusion is based on cumulative finds in churches and written documents. Sweden had a limited number of coins in circulation before 1250. Thus this requisite precondition of re-coinage corresponded well with the underlying situation in Sweden. The increased monetization at the close of the $13^{\text {th }}$ century is in line with the known history of the founding of new towns and emergence of local markets in Sweden. ${ }^{28}$ In medieval Swedish urbanity the demand for local coins must have increased substantially (compare with section 2). Gotland is presumably the region in Scandinavia that had the most coins per capita, and thus would be the worst alternative for short-lived coins.

According to Jonsson (1983:76-77), the volume of coins was larger in Götaland in the period 1250-90 than in Svealand. The cumulative finds in churches in the $13^{\text {th }}$ century corroborate this conclusion (Klackenberg 1992a:179ff). Furthermore, before 1250, there are considerably more different bracteate types in Svealand than in Götaland (see Table 3). Taken together, these facts suggest more frequent renewals in Svealand than in Götaland.

The rule of thumb that the bracteates got a foothold in areas with no established monetary standard (see section 3.3) fits Sweden very well. ${ }^{29}$ The region which later would constitute "Sweden" had none of its own minting for 120 years from 1030 to 1153 . From ca. 1153 to 1290 , the bracteate was the only minted coin type on the mainland.

\footnotetext{
${ }^{27}$ His definition of monetization is that while most peasants used coins, barter was still dominating for local transactions.

${ }^{28}$ In the $13^{\text {th }}$ century, several new towns emerge like Söderköping, Kalmar, Jönköping, Skänninge, etc., in Götaland and Stockholm, Nyköping, Örebro, Arboga, etc., in Svealand. Several new mints were also established.

${ }^{29}$ In Norway, where there seems to have been a break in the coinage at the beginning and middle of the $12^{\text {th }}$ century, the bracteates dominated from ca. 1150 for 130 years. Denmark had a continuous coinage from the end of the $10^{\text {th }}$ century until the 1370s, and its own monetary standard since the 1070s. Denmark in Jutland minted bracteates only sporadically during a single decade, 1146-57.
} 
The theory predicts that debasements should occur in regions with long-lived coins. Therefore, the constant weight (0.30 g in Svealand and $0.15 \mathrm{~g}$ in Götaland) and high silver fineness (95 percent) of the Swedish bracteates until 1250 support the hypothesis of shortlived coins. If the coin issuer can make a profit on re-coinage, debasements are not required. After 1250, when the royal minting increased in volume and the currency areas merged, there are fewer coin types per time period. The debasements as income compensation start after 1250 and continue until 1520. This scenario is exactly as the theory predicts. Previous studies of Swedish bracteates (see e.g. Jonsson 2002:49-50) have not linked the coinage system to the volume of coins in circulation and debasements.

Jonsson (1995:56) has suggested that re-coinage would have occurred with an interval of a specific number of years, primarily with shifting regents in Svealand and western Götaland from 1200, and in eastern Götaland from 1250. In western Götaland, each bracteate type would have been valid for 6-8 years. However, this approach appears badly flawed because frequent re-coinage had already occurred during the reign of King Canute I (1167-96). We know from the historical record that there are a great many types of bracteates between 1180 and 1196, and that the hoards had a skewed composition (see section 4.2). Some of the bracteate types from Sigtuna in the period 1180-96 are stylistically similar to each other, but so many types could not have been valid at the same time. It would only have caused confusion.

Jonsson (1995:56) suggests that the system with re-coinage continued until 1363. He bases this conclusion on written sources about re-coinage in 1340, 1354 and 1363. However, these were not normal re-coinage, where typically only the portrayed image of the coins changed. To the contrary, and this is a key point, they were rather coinage reforms. The coin type and monetary standard were overall changed and replaced by a new one in 1290, 1319, 1354 and 1363. Only the change in 1340 can be seen as a normal re-coinage.

The large geographical area of Sweden tells against the theory of frequent coin renewals. However, Sweden was divided into three separate currency areas until 1250 (see Map 2). Each area was not larger than Denmark. This fact facilitates frequent renewals. An argument against re-coinage might claim Sweden was simply insufficiently developed to administrate such a system at the end of the $12^{\text {th }}$ and beginning of the $13^{\text {th }}$ centuries. Hemmingsson 
(2005:74-75) claims that it is more likely that re-coinage was undertaken only at the end of the $13^{\text {th }}$ century, rather than 100 years earlier, due to the limited administrative capacity of the royal government. He presumes short-lived coins to be an advanced coinage system. However, this is patently wrong. The historical record from continental Europe (see sections 3.1 and 3.3) contains indisputable evidence that it was undeveloped regions and founded cities with low experience of coinage and few coins in circulation that chose a short-lived coinage system. Bracteates in these circumstances were often chosen as the coin type. The Swedish administrative capacity was no doubt improved at the end of the $13^{\text {th }}$ century, but using that observation to justify a fictive chronology is manifestly circular reasoning. In point of fact, the monetization, volume of coins in circulation and number of marketplaces increased even faster. Moreover, the currency area had grown substantially. These factors probably made it near impossible for the Swedish kings to maintain a system with frequent re-coinage at the close of the $13^{\text {th }}$ century.

Between 1200 and 1250, there are not many registered coin hoards in Sweden, but the few existing ones contain almost only Swedish coins (Jonsson 1995:57). However, the cumulative finds in churches in the period 1150-1250 tell another story. In Götaland, Norwegian coins account for 35-60 percent and domestic (Geatish) coins for ca. 30-45 percent of the coins (Klackenberg 1992a:181). In Svealand, domestic pennies account for 65 percent of the coins (and Gotlandic for the rest) in churches in the period 1200-50 (Klackenberg 1992a:186). Therefore, it can be argued that the Swedish king did not have full control over the coin circulation and could not exclude foreign coins (e.g. Runer 2006:86). In such case, it would be difficult to undertake systematic re-coinage.

However, also German coin hoards from this period contain many non-local coins (see Svensson 2013b:Table 9), although systematic re-coinage were undertaken in almost all German currency areas. Like in Germany (see section 3.3), the system with valid current local coins were only enforced within the city borders in Sweden. In the country-side any coins could be used. It is not until the end of the $13^{\text {th }}$ century and the mid-1300s that written documents tell that country-side transactions are forbidden in Sweden (Yrwing 1965:283ff, Runer 2006:88). Therefore, it is not surprising that foreign coins are found in Swedish coin hoards and cumulative finds in churches in the $13^{\text {th }}$ century, even if the king controlled the coin circulation and enforced re-coinage within the cities. 
We have outlined a host of reasons and evidence that support the view that Sweden, and especially Svealand, had frequent coin renewals in the period 1180-1250; whereas Götaland had this system from 1200-50, though with less frequent renewals than Svealand. Both regions from 1250-90 had less frequent renewals and abandoned them in 1290.

\section{Summary}

The purpose of this study has been to analyze which coinage and monetary taxation policies were applied by the minting authorities in medieval Sweden. A theory of how short-lived and long-lived coinage systems in general work has been applied to Swedish coinage. The Swedish medieval coinage has also been analyzed from an economic perspective and compared with continental coinage systems, which to date have seldom been done. Based on the vast but uneven historical record, it has been long established that Sweden adopted coin types (e.g. Viking-age coins, bracteates, Örtugs, hohlpennies) similar to those minted in continental Europe in various periods of the Middle Ages. This study goes further, demonstrating that Sweden also adopted the corresponding continental coinage and monetary taxation policies linked to these coin types.

Swedish experience is extraordinarily well in line with what one would expect from the theory of short-lived and long-lived coins. The economic backwardness - continuous minting did not start until 1153 - and the limited monetization of the society facilitated re-coinage. In this context the few coins in circulation needed to be re-minted, as few classes in society used the coins and there were a limited number of markets to monitor. The fact that Sweden had separate currency areas (Svealand, Western Götaland and Eastern Götaland) until 1250 also facilitated re-coinage. It is unsurprising that the bracteates got such a stronghold in Sweden for almost 140 years (1153-1290). Here, no monetary standards existed when the bracteates arrived, as the theory predicts. Systematic coin renewals (with varying frequency) were applied from 1180 until 1290, when only bracteates were minted. Thus, a clear pattern emerges that is similar to continental Europe, where the bracteates can be linked to frequent renewals.

For Sweden, we have no written documents that directly attest to re-coinage from 1153 to 1290. However, other methods and propositions have been used to identify such a coinage system: 1) Many different coin types per reign for several Swedish kings (method B); 2) Coin 
hoards which are dominated by a few types (method C); 3) It has also been possible to date different bracteates to specific periods of the kings' reigns. Based on the number of bracteate types, re-coinage was more frequent in Svealand than in Götaland in the period 1180-1250. Furthermore, the Swedish bracteates contained almost pure silver (94 percent) until 1250, like the German bracteates that were frequently renewed. This is consistent with the outlined theory. Between 1250 and 1290 there were considerably fewer bracteate types per time period, so it appears reasonable to argue that renewals must have been less frequent, perhaps every fifth or tenth year. This claim is especially persuasive since Western Götaland and Eastern Götaland - and later Svealand - were joined then into one coinage area.

The number of circulating coins and monetization increased at the end of the $13^{\text {th }}$ century, making re-coinage far more difficult. Bracteates were thus finally replaced by long-lived twofaced coins in 1290. This event puts an end to re-coinage, and the Swedish kings began to accelerate the debasement of the long-lived coins. The kings needed to compensate for the disappearing re-coinage fees by debasing their silver content. Such debasements - interrupted by several coinage reforms - were applied until the beginning of the $16^{\text {th }}$ century.

\section{References}

Arnell, Sven-Erik, 2001, “Var den tidigaste medeltida myntningen i Sverige kyrklig?”. Svensk Numismatisk Tidskrift, 2001:1, pp. 4-11.

Dowd, Kevin and Greenaway, David, 1993, "Currency Competition, Network Externalities and Switching Costs: Towards an Alternative View of Optimum Currency Areas". The Economic Journal, 103(420), pp. 1180-89.

Edvinsson, Rodney, 2011, "Inflation before Paper Money: Debasement Cycles in SwedenFinland 1350-1594”. Scandinavian Economic History Review, 59(2), pp. 166-83.

Edvinsson, Rodney, Franzén, Bo and Söderberg, Johan, 2010, "Swedish Payment Systems 995-1534”, in Rodney Edvinsson, Tor Jacobson and Daniel Waldenström (eds.), Exchange Rates, Prices and Wages, 1277-2008. Ekerlids Förlag, Stockholm, pp. 67-132.

Ekre, Rune, 1988, "Nya märkliga myntningsfynd i Lödöse”. Svensk Numismatisk Tidskrift, 1988:2, pp. 28-31.

Gaettens, Richard, 1963, Die Wirtschaftsgebiete und der Wirtschaftsgebietpfennig der Hohenstaufenzeit. Verlag A Riechmann \& Co, Lübeck.

Grinder-Hansen, Keld, 2000, Kongamagtens krise. Det danske møntvœesen 1241-1340. Museum Tusculanums Forlag, Copenhagen. 
Haupt, Walther, 1954, “Oberlausitzer Brakteatenfunde des 13. Jahrhunderts”, in Werner Coblenz (ed.), Arbeits- und Forschungsberichte zur Sächsischen Bodendenkmalpflege, Vol. 4. Landesmuseum für Vorgeschichte, Dresden, pp. 505-81.

Hävernick, Walter, 1955, Die Mittelalterlichen Münzfunde in Thüringen, VEB Gustaf Fischer Verlag, Jena.

Hemmingsson, Bengt, 2005, "Recension av Jonsson (2002): Utveckling av ekonomin som den speglas i myntningen”. Svensk Numismatisk Tidskrift, 2005:3, pp. 74-75.

Hess, Wolfgang, 2004, “Münzverrufungen der späten Pfennigzeit: Besonders in den Brakteatengebieten Mittel- und Südwestdeutschland”, in Lutz Ilisch, Sönke Lorenz and Heiko Steuer (eds.), Dirham und Pfennige 2. Mittelalterliche Münzprägung in Südwestdeutschland. Zeitschrift für Archäologie des Mittelalters. Beiheft 19. Dr Rudolf Habelt GmbH, Bonn, pp. $11-22$.

Holmberg, Kjell, 1995, “När kungens mynt blev allmogens mynt. En översikt över mynt, myntning och myntens roll i det svenska samhället under 1200-talet”. Numismatiska Meddelanden XL, Swedish Numismatic Society, Stockholm, pp. 63-82.

Holmberg, Kjell, 2009, “Karl Knutssons penningar från Åbo”, in Harald Nilsson (ed.), Opus Mixtum, Studia Numismatica Upsaliensia 4. Uppsala University Coin Cabinet, Uppsala.

Jesse, Wilhelm, 1967, Die Wendische Münzverein. Second edition. Klinkhardt \& Biermann, Brunswick.

Jonsson, Kenneth, 1977, "Fastlandsmyntningen under Birger Magnusson (1290-1318) med utgångspunkt från skatt- och lösfynd”. Nordisk Numismatisk Årsskrift 1975-76, pp. 83-161.

Jonsson, Kenneth, 1983, “Översikt över fastlandsmyntningen ca 1180-1250”. Numismatiska Meddelanden XXXIV. Swedish Numismatic Society, Stockholm, pp. 75-103.

Jonsson, Kenneth, 1995, “Från utländsk metall till inhemskt mynt”. Numismatiska Meddelanden XL, Swedish Numismatic Society, Stockholm, pp. 43-61.

Jonsson, Kenneth, 1999, "Myntreformen i Svealand 1216", in Kjell Holmberg and Harald Nilsson (eds.), Samlad Glädje. Numismatiska Klubben i Uppsala 1969-1999. Numismatiska Klubben i Uppsala, Uppsala, pp. 77-86.

Jonsson, Kenneth, 2002, “Utvecklingen av ekonomin som den speglas av myntningen”, in Lin Annerbäck (ed.), Birger Jarls tid - en brytningstid? Sex föreläsningar från ett symposium i Stockholm våren 2001. Runica et Mediævalia, Stockholm, pp. 43-72.

Klackenberg, Henrik, 1992a, Moneta Nostra. Monetarisering i medeltidens Sverige. Almqvist \& Wiksell, Stockholm.

Klackenberg, Henrik, 1992b, “Penningar Blå - franska, norska eller svenska?”, Nordisk Numismatisk Årsskrift 1991, Stockholm, pp. 123-40. 
Kluge, Bernd, 2007, Numismatik des Mittelalters: Handbuch und Thesaurus Nummorum Medii Aevi. Münzkabinett Staatlichen Museen zu Berlin and Verlag der Österreichischen Akademie der Wissenschaften, Berlin and Vienna.

Lagerqvist, Lars O., 1970, Svenska mynt under vikingatid och medeltid samt Gotländska mynt. Numismatiska Bokförlaget, Stockholm.

Malmer, Brita, 1980, Den senmedeltida penningen i Sverige. Kungliga Vitterhets Historie och Antikvitets Akademien. Antikvariska serien 31. Almqvist \& Wiksell, Stockholm.

Malmer, Brita, 2010, Den svenska mynthistorien. Vikingatiden ca 995-1030. The Royal Coin Cabinet and the Swedish Numismatic Society, Stockholm.

Myrberg, Nanouschka, 1995, Myntningen under Magnus Ladulås 1275-90. Stencile. Department of Archaeology and Classical Studies, Stockholm University.

Myrberg, Nanouschka, 2008, Ett eget värde. Gotlands tidigaste myntning, ca 1140-1220. Ph.D. thesis. Department of Archaeology and Classical Studies, Stockholm University.

Nau, Elisabeth, 1977, "Münzen und Geld in der Stauferzeit”, in Christian Väterlein, Ursula Schneider and Hans Klaiber (eds.), Die Zeit der Staufer. Band III. Württembergisches Landesmuseum, Stuttgart, pp. 87-102.

Paszkiewicz, Borys, 2008, “A Chronology of the Teutonic Prussian Bracteates”, in Michael Andersen, Helle W. Horsnæs and Jens Christian Moesgaard (eds.), Magister Monetae. Studies in Honour of Jørgen Steen Jensen. National Museum, Copenhagen, pp. 171-186.

Runer, Johan, 2006, “Den äldsta svenska myntningen - dess funktion och utveckling”, Situne Dei, 2006, pp. 81-94.

Sargent, Thomas and Velde Francois, 2003, The Big Problem of Small Change. Princeton University Press, Princeton and Oxford.

Sejbal, Jirí, 1997, Základy peněžního vývoje. Masarykova univerzita, Brno.

Spufford, Peter, 1988, Money and Its Use in Medieval Europe. Cambridge University Press, Cambridge.

Steguweit, Wolfgang, 1987, Geschichte der Münzstätte Gotha vom 12. bis zum 19. Jahrhundert. Hermann Böhlaus Nachfolger, Weimar.

Suchodolski, Stanislaw, 2012, "Polityka mennicza a wydarzenia polityczne w Polsce we wczesnym średniowieczu" (Minting policy and political events in Poland in the early Middle Ages), in Stanislaw Suchodolski (ed.), Numizmatyka średniowieczna. Moneta źródłem archeologicznym, historycznym i ikonograficznym, Warsaw, pp. 341-348.

Sussman, Nathan, 1993, "Debasements, Royal Revenues, and Inflation in France during the Hundred Years’ War, 1415-22”. The Journal of Economic History, 53(1), pp. 44-70. 
Svensson, Roger, 2013a, "Re-Coinage as a Monetary Tax: Conditions, Consequences and Comparisons with Debasement”. IFN Working paper No. 950, Stockholm.

Svensson, Roger, 2013b, Renovatio Monetae: Bracteates and Coinage Policies in Medieval Europe. Spink \& Son, London.

Vorel, Petr, 2000, Od pražského groše ke koruně české. Průvodce dějinami peněz v českých zemích. Rybka, Praha.

Yrwing, Hugo, 1965, “Landsköp”, Kulturhistoriskt lexikon för nordisk medeltid. Band X. Allhem, Malmö, pp. 283-91. 